Etikonomi

Volume 16 (1), April 2017

P-ISSN: 1412-8969; E-ISSN: 2461-0771

Page $81-92$

\title{
THE EFFECT OF FINANCIAL REPORTING QUALITY ON FINANCING AND INVESTMENT
}

\author{
Windy Angela, Rilya Aryancana \\ Universitas Padjadjaran \\ windyangelalin@gmail.com, rilya@unpad.ac.id
}

\begin{abstract}
.
This paper analysis the effect of reporting quality on financing and investment. It is important for us to understand the relation among them in order to prepare Indonesian companies for ASEAN Economic Community in 2015. The study examines the effect of financial reporting quality on financing and investment of 15 Indonesian companies with large market capitalization based on the Standard and Poor's Rating Services in its first survey of the major corporate credit trends in the Association of Southeast Asian Nations (ASEAN). Those companies may still be under-investing in relation to its regional peers. The results suggest that (1) financial reporting quality has negative effect on financing. (2) financial reporting quality has positive effect on investment among companies with higher likelibood of over-investing and negative effect on investment among those with higher likelihood of under-investing.
\end{abstract}

Keywords: financial reporting quality, financing, investment

\begin{abstract}
Abstrak.
Artikel ini menganalisis dampak kualitas laporan kenangan terhadap pembiayaan dan investasi. Hal ini penting dipahami untuk mengetahui bubungan antar mereka pada perusabaan di Indonesia untuk. menghadapi masyarakat ekonomi ASEAN tahun 2015. Penelitian ini akan menguji pengaruh kualitas laporan keuangan terbadap pembiayaan dan investasi pada 15 perusahaan ekonomi Indonesia yang memiliki kapitalisasi besar menurut peringkat yang dikeluarkan oleh Standard and Poor's. Hal ini merupakan survey pertama atas perusahaan-perusabaan besar di negara anggota ASEAN. Perusahaanperusabaan tersebut mungkin masih memiliki investasi yang dibawah standar dibandingkan perusahaan sejenis di kawasan. Hasil penelitian ini menyarankan bahwa: (1) kualitas laporan keuangan memiliki pengaruh negatif terhadap pembiayaan. (2) kualitas laporan keuangan pada perusahaan memiliki pengaruh positif terhadap kegiatan investasi lebih dan berpengaruh negatif terhadap perusahaan yang memiliki kegiatan investasi kurang.
\end{abstract}

Kata Kunci: kualitas laporan keuangan, pembiayaan, investasi.

Received: January 10, 2017; Revised: February 10, 2017; Approved: March 14, 2017 
The Effect of Financial Reporting ..........

Windy Angela, Rilya Aryancana

\section{INTRODUCTION}

In relation to its regional peers, Indonesian companies may still be underinvesting as a consequence of limited capital spending, conservative balance sheet management and a lack of financial market depth, a new report by rating agency Standard \& Poor's (S\&P) Rating Services finds. Meanwhile, as the deadline approaches for the ASEAN Economic Community (AEC) in 2015, the S\&P estimates that the integration will lead to higher penetration in the country's capital market and banking sector in the long term, opening the way for companies to source external funding. As a result, Indonesian companies will face higher competition from their counterparts, which view the country as an attractive, growing market.

The S\&P's first survey of ASEAN's most prominent companies sheds light on the credit risk trends for the region's corporate sector including 15 companies with the largest market capitalization in Indonesia. Given the fact that these 15 companies still under-invest and adopt a conservative use of debt and that a conservative balance sheet management affects companies' capability to invest optimally, this paper tries to extend the study of these companies by investigating the role of reporting quality as a whole on financing and investment as it is undeniably important for us to understand the relation among them in order to better prepare Indonesian companies in particular and Indonesia in general for AEC in 2015.

It is undeniable that managers' financing choices rely heavily on the financing capacity of the companies. The role of financial reporting quality on financing is one of the crucial questions in accounting research. Financial statement information is particularly important for contracting purposes (Watts and Zimmerman, 1990; Ball, 2003; Holthausen and Watts, 2001).

Moreover, because of its role in reducing information asymmetry, we can also relate financial reporting quality to investment. Biddle, et.al (2009) suggest:

"Higher financial reporting quality could allow constrained companies to attract capital by making their positive net present value (NPV) projects more visible to investors and by reducing adverse selection in the issuance of securities. Alternatively, higher financial reporting quality could curb managerial incentives to engage in value destroying activities".

In other words, higher financial reporting quality can relate to investment by either eliminating financing constraints to increase investment or increasing transparency that may discourage managers to over-invest. 
The relation among information asymmetry, financing, and investment is the subject of a large literature in corporate finance (Hubbard, 1998; Baker, et.al, 2003). More recently, researchers have begun to study whether and how reporting quality mitigates underinvestment associated with financing constraints (Biddle, et.al, 2009). This paper is closely related to recent works that try to highlight the role of financial reporting quality on financing and investment efficiency. Balakrishnan, et.al (2013) examine the relation between reporting quality and financing and investment by using evidence from changes in financing capacity. Biddle, et.al (2009) provide evidence of both in documenting a conditional negative (positive) association between financial reporting quality and investment for companies operating in settings more prone to over-investment (underinvestment). These papers use financial reporting data of companies located in the United States whose domestic capital markets remain the largest and deepest globally (U.S Chamber of Commerce, 2008). This might affect the degree of information asymmetry and financing frictions that companies face, and hence lead to an upward bias of the effect.

Most of this literature shows that higher quality financial reporting can enhance investment efficiency by mitigating information asymmetries that cause economic frictions such as moral hazard and adverse selection (Leuz and Verrecchia, 2000; Bushman and Smith, 2001; Verrecchia, 2001). Nevertheless, there is less research on whether reporting quality serves an information role that alleviates financing constraints. Biddle, et.al. (2009) provide initial evidence of this link by showing that among companies more likely to under-invest, reporting quality is positively associated with investment. This paper extend their paper by linking financing reporting quality to both financing and investment.

This paper also investigate whether financial reporting quality is related to investment. In order to examine the relation between financial reporting quality and investment, this paper follow Biddle, et.al (2009) and categorize companies into two subsamples based on their propensity to under- or over-invest. The question whether financial reporting quality affects investment in this setting is not sufficiently addressed by prior researches because there are only a few studies on this particular topic.

Higher financial reporting quality relates to investment among companies with higher likelihood of over-investing by increasing transparency that may discourage managers to engage in value-destroying activities. 
Thus, higher financial reporting quality relates to investment among companies with higher likelihood of under-investing by reducing adverse selection and eliminating financing constraints. Given these evidences, financing is not the only reason why financial reporting quality can affect investment. It can directly affect investment by decreasing moral hazard and therefore discouraging managers to over-invest.

If reporting quality mitigates adverse selection and moral hazard problems, it can certainly be linked to investment since these two risks encountered by capital suppliers are the major factors that contribute significantly to managers' investment decisions. In studying this relation, we also must not disregard companies' likelihood to over- or underinvest which is indicated by the availability of capital because the degree of likelihood may modify the original relationship between financing reporting quality and investment.

\section{METHOD}

This paper is going to examine two hypotheses. First, this paper is going to examine the effect of financial reporting quality on financing. Second, this paper is going to investigate the effect of financial reporting quality on investment among companies with higher likelihood of over- or under-investing. It is going to use firm-specific characteristics to classify companies with higher likelihood of over- or under-investing.

The sample used for this paper comprises 15 large Indonesian companies analyzed by the Standard and Poor's Rating Services in its first survey of the major corporate credit trends in the Association of Southeast Asian Nations (ASEAN). These are most representative of major industrial sectors in Indonesia due to their large market capitalization.

Follow the approach of Balakrishnan, et.al (2013). Total financing proposed by the company as the dependent variable.

$\mathrm{FIN}^{\sim} \mathrm{NET}_{t+1}=a+\beta_{1} \mathrm{FRQ}_{t}(1)$

Following Bradshaw, Richardson, and Sloan (2006), this paper measure net debt financing as the net cash received from (paid for) the issuance (reduction) of debt. Total financing is the sum of debt and equity financing in a given year scaled by the lagged value of assets. FIN NET is the sum of debt and equity financing in a given year scaled by the lagged value of assets. As before, $F R Q$ is the proxy for reporting quality. 
Follow the approach of Biddle, et.al (2009). This paper test whether financial reporting quality is negatively or positively associated with investment when companies are more likely to over-invest (under-invest).

$$
\text { Investment }_{t+1}=a+\beta_{1} \mathrm{FRQ}_{i, t}+\beta_{2} \mathrm{FRQ}_{i, t} * \operatorname{OverI}_{i, t+1}+\beta_{3} \operatorname{OverI}_{i, t+1}(2)
$$

In order to test the conditional relation between reporting quality and investment, this paper use firm cash balances and leverage as the proxies for over- and underinvestment.

The main measure of investment includes both capital and non-capital investment. FRQ is the measure of financial reporting quality. OverI is a ranked variable used to distinguish between settings where over- or under- investment is more likely. This paper estimate Equation 2 by using Ordinary Least Squares (OLS). Hypothesis $H_{2 b}$ predicts that financial reporting quality is negatively associated with underinvestment.

This paper use timely loss recognition as a proxy for financial reporting quality. The model assumes that positive and negative returns are proxies for economic gains and losses, respectively. For the purpose of measuring the timely loss recognition, this paper follow Khan and Watts' (2009) approach to constructing a measure of conservatism at the firm-year level. This approach uses cross-sectional regression model specified as follows:

$$
X_{i}=a+\beta_{1} D_{i}+\beta_{2} R_{i}+\beta_{3} D R_{i}+\varepsilon_{i}
$$

Where $i$ is firm index, $X$ is annual earnings scaled by the beginning-of-year market value of equity, $R$ is 12 -month stock returns used to measure economic news over the 12 month beginning nine months before the fiscal year end, $D$ is a dummy variable set equal to one when $R<0$ and equal to zero otherwise, and $\varepsilon$ is the residual. Annual earnings represent the amount of net income earned by each company every year. Stock return is calculated with the formula of holding-period return, which comprises of the dividend yield plus the capital gain yield.

The timeliness measure for good news is captured by $\beta_{2}$, whereas the incremental timeliness for bad news over good news is captured by $\beta 3$, which is used to measure conditional conservatism. The total timeliness of bad news is captured by $\beta_{2}+\beta 3$ (Khan and Watts, 2009). If $\beta_{3}$ is positive, the recognition of bad news is timely. Likewise, positive $\beta_{2}$ shows that the recognition of good news is timely. The sum of these two coefficients 
determines the degree of the total timeliness of bad news with a positive value showing a timely recognition and vice versa.

\section{RESULT AND DISCUSSION}

\section{Descriptive Statistics}

Table 1 describes financing in 15 Indonesian companies included in the sample during the period of 2009 to 2013. Financing is proxied by FIN NET, the sum of debt and equity financing in a given year scaled by the lagged value of assets. The highest mean is resulted in 2013 while the lowest mean is resulted in 2009. This suggests that financing increases from year to year.

Table 1. Summary of Financing in 15 Indonesian Companies

\begin{tabular}{cccccc}
\hline No & \multicolumn{5}{c}{ FIN NET $_{\text {t+1 }}$ (Financing) } \\
& $\mathbf{2 0 0 9}$ & $\mathbf{2 0 1 0}$ & $\mathbf{2 0 1 1}$ & $\mathbf{2 0 1 2}$ & $\mathbf{2 0 1 3}$ \\
\hline 1 & $-0,070$ & 0,031 & 0,054 & $-0,004$ & $-0,043$ \\
2 & $-0,329$ & $-0,204$ & $-0,012$ & 0,016 & 0,018 \\
3 & $-0,074$ & $-0,064$ & 0,057 & 0,006 & 0,090 \\
4 & $-0,208$ & $-0,195$ & $-0,587$ & $-0,345$ & $-0,383$ \\
5 & $-0,090$ & $-0,062$ & $-0,077$ & $-0,059$ & $-0,073$ \\
6 & 0,047 & 0,028 & 0,040 & $-0,007$ & 0,112 \\
7 & $-0,003$ & 0,055 & $-0,006$ & 0,053 & 0,039 \\
8 & $-3,594$ & $-0,087$ & $-0,063$ & $-0,107$ & $-0,062$ \\
9 & 0,005 & 0,244 & 0,065 & 0,085 & 0,046 \\
10 & $-0,090$ & $-0,055$ & $-0,233$ & $-0,128$ & $-0,105$ \\
11 & $-0,114$ & $-0,102$ & $-0,019$ & $-0,058$ & $-0,086$ \\
12 & $-0,070$ & $-0,097$ & $-0,154$ & $-0,074$ & $-0,115$ \\
13 & $-0,375$ & $-0,380$ & $-0,461$ & $-0,400$ & $-0,427$ \\
14 & 0,095 & $-0,011$ & $-0,104$ & 0,058 & 0,083 \\
15 & $-0,059$ & $-0,118$ & $-0,018$ & 0,048 & 0,062 \\
\hline Mean & $-0,329$ & $-0,068$ & $-0,101$ & $-0,061$ & $-0,056$ \\
Maximum & & & $-0,056$ & \\
Minimum & & $-0,329$ & \\
\hline
\end{tabular}

Source: data analysis

Table 2 describes investment in 15 Indonesian companies included in the sample during the period of 2009 to 2013. Investment in a given firm-year is the sum of capital expenditures, R\&D expenditures, and acquisitions minus sales of PPE, scaled by lagged total assets. The highest mean is resulted in 2010 while the lowest mean is resulted in 2009. This suggests that investments decrease in the last three years. 
Table 2. Summary of Investment in 15 Indonesian Companies

\begin{tabular}{cccccc}
\hline \multirow{2}{*}{ No } & \multicolumn{5}{c}{ INVESTMENT } \\
& $\mathbf{2 0 0 9}$ & $\mathbf{2 0 1 0}$ & $\mathbf{2 0 1 1}$ & $\mathbf{2 0 1 2}$ & $\mathbf{2 0 1 3}$ \\
\hline 1 & 0,060 & 0,085 & 0,095 & 0,068 & 0,048 \\
2 & 0,033 & 0,074 & 0,224 & 0,201 & 0,172 \\
3 & 0,049 & 0,040 & 0,059 & 0,096 & 0,136 \\
4 & 0,035 & 0,024 & 0,021 & 0,042 & 0,090 \\
5 & 0,030 & 0,037 & 0,041 & 0,061 & 0,093 \\
6 & 0,077 & 0,069 & 0,062 & 0,093 & 0,183 \\
7 & 0,109 & 0,849 & 0,130 & 0,027 & 0,024 \\
8 & 0,151 & 0,084 & 0,101 & 0,115 & 0,119 \\
9 & 0,014 & 0,009 & 0,040 & 0,058 & 0,026 \\
10 & 0,070 & 0,047 & 0,028 & 0,054 & 0,151 \\
11 & 0,316 & 0,273 & 0,213 & 0,245 & 0,102 \\
12 & 0,234 & 0,158 & 0,142 & 0,088 & 0,186 \\
13 & 0,335 & 0,431 & 0,473 & 0,386 & 0,354 \\
14 & 0,153 & 0,159 & 0,267 & 0,143 & 0,082 \\
15 & 0,182 & 0,188 & 0,237 & 0,324 & 0,227 \\
\hline Mean & 0,123 & 0,168 & 0,142 & 0,133 & 0,133 \\
Maximum & & & 0,168 & & \\
Minimum & & & 0,123 & & \\
\hline Source & & & & &
\end{tabular}

Source: data analysis

Table 3 provides the summary of the timely loss recognition each year. Positive results shown in 2008, 2010, and 2011 indicate that the loss recognition is timely in those years. Meanwhile, negative results in 2009 and 2012 indicate untimely loss recognition. In other words, the amounts of earnings reported in 2009 and 2012 are not reflective of the economic conditions throughout those particular years. In general, it can be inferred that the total timeliness for bad news is fluctuating during the period of 2008 to 2012. Therefore, the financial reporting quality varies from year to year.

Table 3. Summary of Timely Loss Recognition (TLR)

\begin{tabular}{lllll}
\hline \multicolumn{1}{c}{ Year } & \multicolumn{1}{c}{$\beta_{2}$} & \multicolumn{1}{c}{$\beta_{3}$} & \multicolumn{1}{c}{$\beta_{2}+\beta_{3}$} & \multicolumn{1}{c}{ TLR } \\
\hline 2008 & 0.089 & -0.056 & 0.033 & Timely \\
2009 & 0.174 & -0.483 & -0.309 & Not Timely \\
2010 & 0.030 & -0.010 & 0.020 & Timely \\
2011 & 0.035 & 0.000 & 0.035 & Timely \\
2012 & -0.002 & -6.702 & -6.704 & Not Timely \\
\hline
\end{tabular}

Source: data analysis 
Table 4 shows the regression result that going to analyze the effect of financial reporting quality on financing. The regression model resulted is as follows: FIN $\sim \mathrm{NET}_{t+1}=-0.140-0.012 \mathrm{FRQ}_{t}$

The constant $a$ of -0.140 means that the mean value of FIN $\sim$ NET is -0.140 if the value of financial reporting quality equals zero. Moreover, the regression coefficient of -0.012 means that FIN NET decreases by 0.012 when the value of financial reporting quality increases by 1 .

Table 4. The Effect of Financial Reporting Quality on Financing

\begin{tabular}{|c|c|c|c|c|c|c|}
\hline \multirow[t]{2}{*}{ Model } & & \multicolumn{2}{|c|}{$\begin{array}{c}\text { Unstandardized } \\
\text { Coeff }\end{array}$} & \multirow{2}{*}{$\begin{array}{c}\text { Standardized } \\
\text { Coeff } \\
\text { Beta }\end{array}$} & \multirow[t]{2}{*}{$\mathrm{t}$} & \multirow[t]{2}{*}{ Sig } \\
\hline & & B & SE & & & \\
\hline \multirow[t]{2}{*}{1} & (Constant) & -.140 & .057 & & -2.475 & .016 \\
\hline & FRQt & -.012 & .019 & -.076 & -.652 & .516 \\
\hline
\end{tabular}

Source: data analysis

The result of the first hypothesis testing shows that financial reporting quality has negative effect on financing. Given this result, the null hypothesis is accepted and the alternate hypothesis is rejected. However, the result does not show that an increase financial reporting quality is in line with an increase in financing. Having considered the result, several possibilities exist. First, it is possible that most of the companies included in the sample do not face financing constraints (Balakrishnan, et.al, 2013). This condition renders financial reporting quality irrelevant with financing because companies can have access to financing regardless of financing constraints, such as financing costs.

Second, companies operating in higher-risk environments, such as Indonesia, may adopt less risky financing policies. Indonesia is considered as having higher-risk environments due to its lack of financial market depth and high dependence on foreign investors. The S\&P's first survey of ASEAN's most prominent companies finds that the most notable difference in the country distribution of financial risk profiles is the significantly more conservative nature of Indonesian companies. Taking into account key financial ratios including debt to EBITDA, EBITDA interest coverage, and free operating cash flows to debt, the financial risk profiles of 13 out of 15 Indonesian companies are "minimal," "modest," or "intermediate". Corresponding to this situation, Indonesian firms may still prefer to use their own internal cash flow to finance growth. Therefore, high financial reporting quality intended to reduce information asymmetry does not have the expected effect on external financing because of companies' reliance on internal financing. 
Third, experiencing political instability, higher energy costs, and monetary policy tightening, Indonesia's stock market is considered to be the most risky in Southeast Asia. According to this report, Indonesia's stock market is most vulnerable to capital flight amid expensive valuations and large holdings by foreign investors. In this case, besides financial reporting quality, there can be so many factors that affect companies' ability to obtain financing because investors are exposed to the risks other than those caused by information asymmetry, including the systematic risks resulted from domestic issues. Fourth, regardless of their ability to obtain financing, some companies may prefer not to issue more shares to retain the ownership of existing shareholders. This reason could probably explain why in this research period, only a few companies issue more shares and most companies have negative equity financing.

Table 5. The Effect of Financial Reporting Quality on Investment

\begin{tabular}{llccccc}
\hline Model & & \multicolumn{2}{c}{ Unstandardized } & Standardized & t & Sig \\
& & Coeff & & & \\
& & Coeff & & & \\
\hline 1 & (Constant) & .256 & .057 & & 4.490 & .000 \\
& OverIt,t+1 & -.208 & .099 & -.265 & -2.110 & .038 \\
& FRQt & -.008 & .020 & -.152 & -.373 & .710 \\
& FRQ*Over & -.015 & .035 & -.180 & -.439 & .662 \\
\hline
\end{tabular}

Source: data analysis

The regression model resulted is as follows:

Investment $_{t+1}=0.256-0.008 \mathrm{FRQ}_{i, t}+0.015 \mathrm{FRQ}_{i, t}{ }^{*} \operatorname{OverI}_{i, t+1}+0.208$ OverI $_{i, t+1}$

The constant is 0.256 , means that the mean value of investment is 0.256 if it is not affected by any of the independent variables. Moreover, the first regression coefficient of 0.008 means that investment decreases by 0.008 when the value of financial reporting quality increases by 1 . Table 5 examines the effect of financial reporting quality on investment. The model of the second hypothesis is specified as follows:

$$
\text { Investment }_{t+1}=a+\beta_{1} \mathrm{FRQ}_{i, t}+\beta_{2} \mathrm{FRQ}_{i, t} * \text { OverI }_{i, t+1}+\beta_{3} \text { OverI }_{i, t+1}
$$

Where Investment in a given firm-year is the sum of capital expenditures, R\&D expenditures, and acquisitions minus sales of PPE, scaled by lagged total assets, FRQ is my proxy for reporting quality shown by timely loss recognition, and OverI is a ranked variable used to distinguish between settings where over- or under- investment is more likely. The coefficient $\beta_{1}$ measures the relation between financial reporting quality and investment when under-investment is most likely. The coefficient $\beta_{2}$ measures the incremental relation between financial reporting quality and investment as over-investment 
becomes more likely. The sum of the coefficients on the main and interaction effects $\beta_{1}+$ $\beta_{2}$ ) measures the relation between financial reporting quality and investment when overinvestment is most likely.

Based on the results, the sum of $\beta_{1}$ and $\beta_{2}$ equals $0.007\left(\beta_{1}+\beta_{2}>0\right)$. This indicates that $\mathrm{H}_{02 \mathrm{a}}$ is accepted and therefore financial reporting quality has positive effect on investment among companies with higher likelihood of over-investing. Thus financial reporting quality has negative effect on investment among companies with higher likelihood of under-investing. This result also is supported by the output of the $t$ test. The value of $t$ produced in the test is -0.373 . Because the value of $t(-0.373)$ is bigger than $-t$ in the table $(-1,994)$, the null hypothesis is accepted. The aforementioned results are also followed by the rejected corollary due to positive $\beta_{2}$. That is, as opposed to what is proposed by the corollary, the incremental relation between financial reporting quality and investment as over-investment becomes more likely is positive $\left(\beta_{2}=0.15\right)$.

The second hypothesis is divided into two parts that are conditional on whether the companies are more likely to over- or under-invest. As previously discussed, the results provide evidences for the effect of financial reporting quality on investment in both settings. First, financing reporting quality has positive effect on investment among companies with higher likelihood of over-investing. Second, financial reporting quality has negative effect on investment among companies with higher likelihood of under-investing.

The following are the assumptions underlying the alternate hypothesis. Higher financial reporting quality relates to investment among companies with higher likelihood of over-investing by increasing transparency that may discourage managers to engage in valuedestroying activities. Moreover, higher financial reporting quality relates to investment among companies with higher likelihood of under-investing by reducing adverse selection and eliminating financing constraints. Having the results that turn out to be the opposites of the expected effects, some possibilities arise as what may be the causes of these results. For the companies with higher likelihood of over-investing, the positive effect of financial reporting quality on investment seems plausible because the S\&P's survey of major corporate credit trends suggests that compared to its regional peers, Indonesian firms may still be under-investing as a consequence of limited capital spending. It means that the current investment level of these companies is still considered low. That being the case, an increase in investment may not represent a tendency to over-invest and companies with higher liquidity (hence higher likelihood of over-investing) do not appear to have excessive 
investment when they increase their investment because it may still be under the optimal level. Thus, a better transparency resulted from a higher financial reporting quality does not discourage managers to invest more, considering the probability that these managers are trying to increase profits, instead of engaging in value-destroying activities to cause the companies to grow beyond their optimal size.

For the companies with lower liquidity (hence higher likelihood of underinvesting), there can be some reasons why financial reporting quality does not have positive effect on their investments. First, financial reporting quality may not eliminate financing constraints as expected due to several causes explained in the previous section, such as the absence of financing constraints, less risky financing policies, and political and economic instability. Therefore, a higher financial reporting quality cannot guarantee an increase in financing which is essential to make investment. Second, the riskiness of investment activities may also affect managers' decisions to invest. Companies with lower liquidity need to be more careful than those with higher liquidity in investing because the losses that may be incurred can affect the going concern of these companies in a bigger scale.

\section{CONCLUSIONS}

The findings suggest that financial reporting quality has negative effect on financing and financial reporting quality has positive effect on investment among companies with higher likelihood of over-investing and negative effect on investment among those with higher likelihood of under-investing. Several possibilities ranging from internal to external factors exist as the causes to these results. An opportunity exists to extend this study in several ways. First, one could use different samples or research period in order to explore other possibilities that may happen in regard with this particular topic. Second, this research does not take into account some other factors that are likely to affect financing and investment, such as such as companies' financing policies and riskiness of investment activities.

\section{REFERENCES}

Baker, M., J.C. Stein, J.C. \& J. Wurgler. (2003). When Does the Market Matter? Stock Prices and the Investment of Equity-Dependent Firms. The Quarterly Journal of Economics. Vol. 118, No. 3: 969-1006. 
Balakhrisnan, K., J.E.Core, \& R. Verdi. (2013). The Relation between Reporting Quality and Financing and Investment: Evidence from Changes in Financing Capacity. Journal of Accounting Research. Vol. 52, No. 1: 1-36.

Ball, R., A. Robin., \& J. Wu. (2003). Incentives versus Standards: Properties of Accounting Income in Four East Asian Countries. Journal of Accounting and Economics. Vol. 36, No. 1-3: 235-270.

Biddle, G.C., G. Hillary,\& R. Verdi. (2009). How Does Financial Reporting Quality Relate to Investment Efficiency?. Journal of Accounting and Economics. Vol. 48 (2-3): 112131.

Bushman, R.M. \& A. Smith. (2001). Financial Accounting Information and Corporate Governance. Journal of Accounting \& Economics.Vol. 32, No. 1-3: 237-333.

Holthausen, R.W. \& R. Watts. (2001). The Relevance of the Value-Relevance Literature for Financial Accounting Standard Setting. Journal of Accounting and Economics. Vol. 31, No. 1: 3-75.

Hubbard, G. (1998). Capital-Market Imperfection Investment. Journal of Economic Literature. Vol. XXXVI, No. 1: 193-225.

Khan, M. \& R. Watts. (2009). Estimation and Empirical Properties of A Firm-Year Measure of Accounting Conservatism. Journal of Accounting and Economics. Vol. 28, No. 2-3: 132-150.

Leuz, C. \& R. Verrecchia. (2000). The Economic Consequences of Increased Disclosures. Journal of Accounting Research. Vol. 38: 255-261.

McNicholas, M.F. and Stubben, Stephen. 2008. Does Earnings Management Affects Firms' Investment Decisions?. The Accounting Review. Vol. 82, No. 6, pp. 1571-1603.

Standard \& Poor's Ratings Services. (2014). ASEAN Top Companies. Singapore: McGrawHill Financial.

Verrecchia, R. (2001). Essays on Disclosure. Journal of Accounting \& Economics. Vol. 32, No. 1-3: $97-180$.

Watts, R.L \& J. Zimmerman. (1990). Positive Accounting Theory: A Ten Year Perspective. The Accounting Review. Vol. 65, No. 1: 131-156. 